\title{
Screening for the corrosion inhibition of mild steel metal using biofilm forming halophilic bacteria isolated from the saltpans of Thoothukudi district
}

\begin{abstract}
Metal corrosion is a natural process caused by chemoautotrophic organisms mostly in aerobic condition. In the present study, a new form of protection against corrosion has been identified by applying bacteria isolated from the saltpans of Thoothukudi district. Out of nine strains, only two were shown to have an anti-corrosive action which was later identified as Oceanobacillus oncorhynchi and Pseudomonas stutzeri by molecular identification technique. Bacterial cultures are coated onto the surface of mild steel coupons in a corrosive environment in order to determine the weight loss and corrosion rate. The use of biofilm-forming bacteria shows increasing promise as an effective, safe, cheaper, longterm and environmentally friendly method for controlling corrosion.
\end{abstract}

Keywords: metal biocorrosion, biofilm, Pseudomonas, Thoothukudi saltpan
Volume 6 Issue 5 - 2018

\author{
Deepalaxmi RK,' Gayathri C² \\ Department of Microbiology, St Mary's College, India
}

Correspondence: Department of Microbiology, St Mary's College,Tamilnadu, India, Email deepalaxmi7@gmail.com

Received: June 28, 2018 | Published: September 17, 2018

\section{Introduction}

The term "Metal" is used to any substance that is hard, possessing silvery luster and is a good conductor of heat and electricity. Corrosion is an electrochemical reaction between a metal and its environment, which includes dissolution of metals. Corrosion involves both biotic and abiotic factors. When metals are exposed to water and oxygen, they corrode. ${ }^{1}$ Several environmental factors affect the corrosion rates and the composition of the corrosion products such as metal type, the chemical composition of the bulk water, electrochemistry and microorganisms. ${ }^{2}$ Biocorrosion processes on metal surfaces depend on the physiology of the microbial community developing under the chemical and physical parameters. Recent studies have shown that not all bacteria are harmful to metals but many different bacteria can actually protect them from corrosion. This phenomenon is called are microbiologically influenced corrosion inhibition (MICI). The inhibition of corrosion by bacteria is often accomplished by:

a. A decrease in the corrosive action of the medium in restricted parts of the metal- bulk solution interface, such as by neutralizing the acidity of the medium;

b. the formation of protective films on the metal surface or providing new protective films such as through the production of exopolysaccharide with metal binding abilities and;

c. decreasing the cathodic electron acceptor by microbes. ${ }^{3,4}$ Since corrosion causes dramatic economic loss, corrosion has to be controlled. In this work, corrosion inhibition was studied in Luria Bertani Broth. The study was aimed at identifying the corrosion inhibition bacteria to some extent on mild steel coupons. The organisms possessing anti-corrosive activity was identified by 16S rRNA gene sequencing method.

\section{Materials and methods}

\section{Sampling area}

In this study, the saline soil sample was collected from solar salt pans and coastal areas of Thoothukudi district, Tamilnadu, India. The collected soil samples were placed in sterile polythene bags and containers and immediately transported to the laboratory for further analysis

\section{Isolation of halophilic bacteria from the saline soil sample}

The sample was serially diluted in the range of $10^{-1}, 10^{-2}, 10^{-3}$, $10^{-4}, 10^{-5}, 10^{-6}$, and $10^{-7}$ in a series of the test tube. The halophilic bacteria were cultured in the Mineral Salt (MM63) medium with an increased concentration of $\mathrm{NaCl}(6 \mathrm{~g} / 100 \mathrm{ml})$. The $\mathrm{pH}$ of the medium was adjusted to 7-7.4. The samples were inoculated under an aseptic condition in the Petri plates containing Mineral Salt (MM63) medium using spread plate technique and are incubated at $37^{\circ} \mathrm{C}$ for 48 hours. ${ }^{5}$

\section{Morphological studies}

Gram staining: The morphological test was performed by the procedure from Dussalt. ${ }^{6}$

Metal coupon preparation: Mild Steel coupons were collected, polished with emery paper, and washed with distilled water, ethanol and acetone for its surface sterilization. Then the metal coupons were weighed.

Determination of corrosion inhibition in Luria Bertani Broth: Luria Bertani broth was prepared and sterilized along with the metal coupons. After sterilization, the broth containing the metal coupon was inoculated with the halophilic isolates and incubated under the static condition at $37^{\circ} \mathrm{C}$ for 7 days. After incubation, the weight loss of the metal coupons was recorded. The physical change was recorded by comparison with the control.

a. Physical appearance: After incubation of metal coupons in Luria Bertani broth containing the biofilm forming isolates for a period of 7 days, the metal coupons were retrieved and the appearance of the metal coupons was observed. The test metal coupons were compared with that of the control. 
b. Weight loss determination: Before incubating, the metal coupons were weighed. The weight of Mild Steel was weighed as $20 \mathrm{~g}$. After incubation, the metal coupons were retrieved and weighed to determine the weight loss. The weight loss of test metal coupons was compared with the weight loss of the control metal coupons.

c. Evaluation of corrosion rate: After retrieval, the corrosion products from the metal coupons were removed and dried in an oven. The cleaned metal coupons were weighed. The corrosion rate $\left(\mathrm{mg} . \mathrm{Dm}^{-2} \cdot \mathrm{d}^{-1}\right)$ was then calculated using the formula:

$$
C=W_{1}-W_{2} / A t
$$

Where,

$\mathrm{C}$ is the corrosion rate $\left(\mathrm{mg} \cdot \mathrm{Dm}^{-2} \cdot \mathrm{d}^{-1}\right)$

$\mathrm{W}_{1}(20)$ and $\mathrm{W}_{2}$ are the weights in a gram of metal coupons before and after immersion.

A is the area of the panels $\left(8.64 \mathrm{~cm}^{2}\right)$.

$\mathrm{T}$ is the duration of immersion in days (7days).

\section{Molecular identification}

The halophilic isolate was identified based on 16SrRNA gene sequencing. Briefly, the gDNA was extracted that served as a template for the 16S rRNA gene amplification using universal forward primer (27F) (5'-AGAGTTTGATCMTGGCTCAGTAC-3') and reverse primer (1492R) (5'- GGYTACCTTGTTACGACTT-3') (Biozone (India) Pvt. Ltd.) via standard polymerase chain reaction (PCR) protocol. The amplified gene product $(1 \mathrm{~Kb})$ was checked on a $1.5 \%$ agarose gel against a $1 \mathrm{~Kb}$ DNA ladder. The BLASTn search program was employed to find nucleotide sequence homology.

\section{Results and discussion}

The marine soil sample was collected and was serially diluted. After incubation of 7 days, different colonies were observed. The colonies were separately named and it is subjected to the morphological test (Table 1). Metal steel coupons brought, surface sterilized, weighed and inoculated into Luria Bertani medium. The physical appearance of the metal coupons which was noted initially was then compared with the coupons after the incubation period. The weight loss of test metal coupons was determined to compare with the weight loss of the control metal coupons (Table 2). The corrosion rate was evaluated by the above-given formula and the results were tabulated. The corrosion rate of the test samples DM17 \& DM27 were found to be decreased than the control sample, while the other test samples show increased corrosion rate similar to that of the control sample (Table 2). The test isolates DM17 and DM27 were alone taken into molecular identification. The results of $16 \mathrm{~S}$ rRNA gene sequencing were tabulated (Table 3). Oceanobacillus oncorhynchi and Pseudomonas stutzeri have been shown to decrease the rate of metal corrosion through polymer production during biofilm formation. The increased corrosion resistance was observed when Mild Steel was exposed to complex, nutrient-rich media containing Pseudomonas stutzeri. It is observed that the biofilm may not act as a physical barrier to corrosive agents but, instead of that it reduces the concentration of oxygen at the metal surface by respiration and hence reduced corrosion.

Table I Morphological test results of the halophilic isolates

\begin{tabular}{lllllllllll}
\hline S.NO & Morphological test & DM07 & DMI7 & DM27 & DM37 & DM47 & DM57 & DM67 & DM77 & DM87 \\
\hline I & Staining & - & + & - & - & - & + & - & - & + \\
2 & Motility & + & - & + & - & - & - & - & + & - \\
3 & Shape & Rod & Rod & $\operatorname{Rod}$ & $\operatorname{Rod}$ & $\operatorname{Rod}$ & $\operatorname{Rod}$ & $\operatorname{Rod}$ & $\operatorname{Rod}$ & $\operatorname{Rod}$ \\
\hline
\end{tabular}

Table 2 Weight loss and Corrosion rate determination

\begin{tabular}{llll}
\hline Metal coupons & Initial weight & Final weight & Corrosion rate (mg.Dm-2.d-I) \\
\hline MS Control & 20 & 19 & 0.016 \\
MS Test DM07 & 20 & 18.9 & 0.018 \\
MS Test DM17 & 20 & 19.5 & 0.008 \\
MS Test DM27 & 20 & 19.6 & 0.006 \\
MS Test DM37 & 20 & 18.7 & 0.021 \\
MS Test DM47 & 20 & 18.7 & 0.021 \\
MS Test DM57 & 20 & 18.6 & 0.023 \\
MS Test DM67 & 20 & 18.9 & 0.018 \\
MS Test DM77 & 20 & 19 & 0.016 \\
MS Test DM87 & 20 & 18.9 & 0.018 \\
\hline
\end{tabular}


Table 3 Identification of isolated halophilic strains based on I6S rRNA gene sequence and their accession numbers (BLAST similarity search results)

\begin{tabular}{|c|c|c|c|c|c|}
\hline $\begin{array}{l}\text { Strain } \\
\text { ID }\end{array}$ & $\begin{array}{l}\text { Strain name } \\
\text { / Genus }\end{array}$ & $\begin{array}{l}\text { Number of nucleotides of } \\
\text { I 6S rRNA gene }\end{array}$ & $\begin{array}{l}\text { Accession number of } \\
\text { I 6SrRNA gene }\end{array}$ & $\begin{array}{l}\text { Closely related } \\
\text { taxa }\end{array}$ & $\begin{array}{l}\text { Sequence similarity (\%) of } \\
\text { I 6SrRNA gene }\end{array}$ \\
\hline DMI7 & Oceanobacillus & 1497 & LT22II 88 & $\begin{array}{l}\text { Oceanobacillus } \\
\text { oncorhynchi }\end{array}$ & $92 \%$ \\
\hline DM27 & Pseudomonas & 1150 & $A B I 26690$ & $\begin{array}{l}\text { Pseudomonas } \\
\text { stutzeri }\end{array}$ & $90 \%$ \\
\hline
\end{tabular}

\section{Conclusion}

Biofilm can provide protection from toxic compounds such as antibiotics, thermal stress, and predation. Thus in this study, biological control strategies such as biocompetitive exclusion, show increasing promise as a more effective long term method of corrosion control. This strategy has been shown to be successful at the laboratory and field scale.

\section{Acknowledgments}

None.

\section{Conflict of interest}

There is no conflict to publish our article in this Journal.

\section{References}

1. Hamilton WA. Sulfate-reducing bacteria and anaerobic corrosion. Аnnu Rev Microbiol. 1985;39:195-217.
2. Borenstein SW. Microbiologically influenced corrosion hand book. Wood head, Cambridge, England. 1994.

3. Juzeliunas E, Ramanauskas R, Lugauskas A, et al. Influence of wild strain Bacillus mycoideson metals: From corrosion acceleration to environmentally friendly protection. Electrochem Acta. 2006;51(27):6085-6090.

4. Akpabio EJ, Ekott EJ, Akpan ME. Inhibition and control of microbiologically influenced corrosion in oilfield materials. Environ Res J. 2011;5(2):59-65.

5. Seelay HW, Vandermark PJ. Microbes in Action: A Laboratory Manual of Microbiology. $4^{\text {th }}$ ed. WH Freeman \& Co; 1981. p. 135.

6. Dussault H P. An improved technique for staining red halophilic bacteria. J Bacteriol. 1955;70(4):484-485. 